\title{
ANALISIS PENGUKURAN KINERJA MENGGUNAKAN BALANCE SCORECARD UNTUK MENENTUKAN KEY PERFORMANCE INDICATOR DI PT MULIA ARTHA ANUGERAH
}

\author{
Wakhit Ahmad Fahrudin \\ Dosen Prodi Teknik Industri, Fakultas Teknik, Universitas Pamulang, Tangerang Selatan, Banten \\ dosen01310@unpam.ac.id
}

\begin{abstract}
ABSTRAK
Seiring dengan berjalanya beberapa tahun terakhir PT Mulia Artha Anugerah yang berdiri pada tahun 2017 telah mengalami peningkatan baik dari produksi maupun kinerja karyawanya. Untuk itu perusahaan yang bergerak dibidang minyak dan gas ini membutuhkan pengukuran kinerja dengan menggunakan metode balance scorecard (BSC) untuk mengetahui persentase key performance indicator (KPI) yang sebelumnya hanya menggunakan analisis laporan keuangan tiap tahunya. Tujuan dari penelitian ini dilakukan untuk menentukan persentase kinerja kayawan dengan menggunakan balance scorecard sebagai alat ukur yang berbasis strategis dan bekesinambungan antara perusahaan dengan karyawan. Dalam penelitian ini menggunakan variabel diantaranya adalah prespektif keuangan, prespektif kepuasan pelanggan, prespektif bisnis internal serta perspektif pertumbuhan dan perkembangan. Pengumpulan data dilakukan dengan kuesioner seluruh karyawan PT Mulia Artha Anugerah dari top manajemen sampai karyawan paling bawah. Hasil dari pengolahan data dengan beberapa indikator prespektif keuangan mempunyai rata-rata nilai sebesar 4,33 untuk prespektif kepuasan pelangaan didapatkan nilai 4,33 prespektif bisnis internal mempunyai nilai 3,58 dan dilihat dari prespektif pertumbuhan dan perkembangan mempunyai nilai 3,82. Sehingga dapat disimpulkan bahwa kinerja karyawan PT Mulia Artha Anugerah dilihat dari keempat prespektif diatas nilai ratarata adalah 3,83 yang berarti cukup baik.
\end{abstract}

Kata Kunci : Kinerja, Balance Scorecard, Key Performance Indicator.

\section{PENDAHULUAN}

Perkembangan dunia industri sangatlah pesat dan dituntut untuk bersaing dengan industri-industri pesaing baru yang datang. Secara umumnya dalam pengukuran kinerja dibeberapa perusahaan telah dilakukan, namun dari beberapa perusahan masih banyak pengukuran kinerja dengan menggunakan laporan keungan sebgai alat ukurnya. Namun demikian masih banyak kekurangan dalam penilaian kinerja hanya mengandalakan laporan keuangan saja. Hal ini dinilai dari beberapa karyawan kurang seimbang dalam penilaian kinerjanya karena berkembangnya teknologi dan informasi pada saat ini yang akan mempengaruhi dari beberapa faktor dalam penilaian. Maka diperlukan pengukuran yang berbasis strategis dan terintegrasi dalam menentukan kinerja setiap tahunya dengan upaya menjaga keberlangsungan kerja sama untuk mencapai tujuan perusahaan.
PT. Mulia Artha Anugerah merupakan perusahaan yang bergerak dibidang minyak dan gas (MIGAS) yang berdiri pada tahun 2017. Dalam dua tahun terakhir telah mengalami peningkatan dalam produksi sebagai supplier peralatan pengeboran minyak dibeberapa perusahaan. Dengan meningkatnya permintaan kinerja karyawan dituntut untuk bekerja secara optimal dalam melayani kebutuhan customer tersebut. Dengan demikian perlu adanya pengukuran kinerja karyawan dari beberapa faktor, dalam penelitian ini menggunakan metode balance scorecard dengan variabel empat prespektif diantaranya adalah prespektif keungan, prespektif bisnis internal, perspektif pertumbuhan dan perkembangan serta perspektif kepuasan pelanggan. Diharapakan dengan menggunakan metode ini dapat menilai kinerja dengan maksimal. 


\section{DASAR TEORI}

Dalam penelitian ini mengunakan beberapa teori diantaranya adalah

\section{A. Definisi Kinerja}

Kinerja Perusahaan adalah kegiatan yang dipengaruhi dari operasional perusahaan dalam memanfaatkan sumber daya yang dimiliki dengan keadaan tampilan secara keseluruhan utuh selama periode waktu tertentu yang telah ditentukan perusahaan sebagai hasil prestasi, (Widodo, 2011).

Kinerja merupakan tindakan aktifitas sebagian atau keseluruhan suatu organisasi dengan referensi pada sumber-sumber seperti biaya-biaya masa lalu yang diproyeksikan, dengan akuntabilitas manajemen atau semacamnya pada suatu periode yang secara umum digunakan, (Fauzi, 1995).

Kinerja atau performace adalah program kegiatan melalui perencanaan strategis suatu organisasi yang dituangkan dalam kebijakan, visi dan misi dalam mewujudakan sasaran dan tujuan dalam pencapaian pelaksanaan kegiatan tersebut, (Hidayat, 2018).

Beberapa sumber telah menjelaskan bahwa kinerja perusahaan yang dapat diartikan sebagai ukuran kesepakan antara beberapa departemen untuk meraih pencapaian dari kinerjanya masing-masing. Dari penilaian ini dapat juga menggambarkan bagaimana kondisi internal dan eksternal perusahaan. Dengan demikian berdasarkan beberapa pendapat para ahli diatas dapat disimpulkan bahwa pengertian kinerja adalah tindakan yang dilakukan oleh beberapa orang atau organisasi yang membentuk suatu sistem dalam periode tertentu yang memanfaatkan sumber daya pendukungnya.

\section{B. Pengertian Pengukuran Kinerja}

Pengertian dari pengukuran kinerja (performance measurement) merupakan tindakan dalam mencapai tujuan organisasi dengan menilai kemajuan pekerjaan terhadap tujuan dan sasaran dalam pengelolaan sumber daya manusia yang menghasilkan perusahaan jasa maupun barang, (Hidayat, 2018). Adanya pengukuran kinerja pada perusahaan diharapakan bersinergi untuk menjalin kerja sama memerankan pelaku manusia sebagai pekerja yang unggul dalam bidangnya dan bersaing untuk memberikan kontribusi terhadap organisasi ataupun perusahaan.
Selain dari itu pengukuran kinerja merupakan penentu kriteria-kriteria yang telah ditetapkan perusahaan sebelumnya sebagai tidak lanjut dari suatu organisasi, bagian dari organisasi dan karyawan berdasarkan sasaran, standar secara periodik efektifitas operasional, (Hidayat, 2018).

Dalam penukuran kinerja, para manajer dan atasan dapat memberikan keputusan dalam kebijakan yang akan dilakukan dalam rangka perusahaan bisnis perusahaan. Penentuan keputusan penting salah satunya adalah kenaikan pangkat maupun peningkatan gaji / penghasilan dan sebagainya, ini ditinjau dari segi internal. Jika dilihat dari faktor eksternal penilaian kinerja dapat digunakan sebagai alat pendekteksi awal untuk meramalkan kondisi perusahaan yang akan datang dan sebagai penrik investasi.

Untuk itu pengertian dari pengukuran kinerja dapat disimpulkan bahwa sebuah alat tindakan yang menganalisa operasional dalam perusahaan dari lingkup pemilik perusahaan, manajemen perusahaan dengan karyawan dalam melakukan kerja sama dalam aktifitas berkesinambungan untuk mewujudkan tujuan bersama.

\section{Definisi Konsep Balance Scorecard}

Definisi Balance Scorecard adalah berasal dari kata Balance yang mempunyai arti berimbang dan Scorecard mempunyai arti kartu skor. Dari dua kata tersebut jika digabungkan mempunyai arti bahwa adanya keseimbangan antara performa keuangan atau bukan bagian keuangan, performa jangka panjang yang bersifat internal maupun eternal, yang catat dalam skor performa dari seseorang maupun organisasi dimasa depan, (Kaplan \& David P. Norton, 1996).

\section{Prespektif Balance Scorecard}

Pengukuran kinerja perusahaan dengan menggunkan pendekatan Prespektif Balance Scorecard dapat diwujudkan dengan mengguakan beberapa kriteria berikut:

1. Customer Prespective

Penjelasan dari prespektif kepuasan pelanggan adalah dimana pelanggan mengetahui perusahaan dalam menyediakan barang maupun jasa sesuai dengan kebutuhan yang didasari dengan beberapa keunggulan pada perusahaan tersebut. Hal 
ini menjadi konsentrasi sebuah organisasi ataupun perusahaan dalam memberikan pelayanan dan mengatur strategi dengan harga terjangkau tanpa mengabaikan kualitas dan cepat tepat dalam pengiriman produk yang dihasilkan atau pelayanan dalam organisasi atau perusahaan dibidang jasa. Untuk itu dalam melihat tingkat kepuasan pelanggan dapat diterapkan kedalam 5 dimensi diantaranya adalah

a. Wujud Fisik, sebagai contoh dari pelayanan wujud fisik adalah tempat sarana dan prasarana yang dapat dilihat dan disaksikan oleh pelanggan.

b. Keandalan, merupakan bagian dari pelayanan yang diberikan sesuai dengan kemampuan organisasi maupun perusahaan sesuai dengan tepat waktu yang dijanjikan.

c. Daya tanggap, merupakan bagian dari pelayanan pelanggan dengan mampu memberikan tanggapan sesuai dengan spesifikasi permintaan pelanggan dan penjelasan yang diinginkan.

d. Jaminan, merupakan bagian dari pelayanan pelanggan yang memberikan rasa kepercayaan diri terhadap pelanggan terhadap perusahaan.

e. Empati, adalah jalinan hubungan dengan pelanggan yang baik dari komunikasi baik secara pribadi maupun organisasi / perusahaan yang diberikan kepada pelanggan.

\section{Finansial Prespektif}

Pengukuran terhadap presapektif finansial atau keuangan menjelaskan tentang apa yang diharapakan kebutuhan dari penyedia sumber daya terhadap kinerja pada finansial. Dalam pengukuran keuangan meliputi beberapa dimensi berikut:

a. Efektif, dalam prespektif finansial efektif merupakan kemampuan dalam mengelola keuangan sesuai dengan pencapaian kelebihan target kinerja manajemen atau kebalikanya apakah dalam pengelolaan finansial / keuangan kekuarangan targetnya.

b. Efisiensi, dalam prespektif finansial ditinjau dari segi efisiensi penjesanya adalah dalam melihat besarnya pengeluaran biaya yang dikeluarkan untuk penghasilan pendapatan usahanya, apabila jumlah pengeluaran lebih besar daripada pendapatan usahanya maka dapat disimpulkan bahwa kinerja manajemen tidak efisien. Untuk disebut efisien apabila pengeluaran lebih sedikit daari jumlah pemasukan usaha.

c. Ekonomis, dalam dimensi finansial ekonomis merupakan bagian yang tidak dapat dipisahkan. Hal ini dapat ditinjau dari pengeluaran finansial operasional yang tersedia, apabila aktu pengeluaran aktual lebih kecil daripada anggaran disebut dengan ekonomis, begitu pula jika melakukan penghematan dalam pengeluaran.

3. Internal Processes Prespective

Pada prespektif bisnis internal paling utama diperhatikan adalah menampilkan dari keunggulan perusahaan yang dimiliki. Proses perbaikan secara berkelanjutan dan memilih strategi dalam mengembangkan keunggulanya. Berikut merupakan dimensi dari prespektif Bisnis Internal diantaranya adalah

a. Kepuasan Bekerja, dimensi ini merupakan gambaran dari kepuasan karyawan atau pekerja diperusahaan.

b. Proses, pengertianya adalah memberikan informasi tentang keunggulan karyawan dalam salah satu bidang dalam memberikan pelayanan pada konsumen.

c. Sarana dan Prasarana, dimensi ini merupakan gambaran dari kondisi tempat dan perlengkapan dalam pendukung kegiatan yang dimiliki.

4. Learning Growth Prespective

Pada dimensi ini menjelaskan tentang Pembelajaran dan Pertumbuhan bagaimana perusahaan selalu continous improvement dalm menambah nilai untuk customer dan stakeholdernya. Maka dengan adanya continous improvement diharapkan selalu inovasi terus menerus mengembangkan pertumbuhan yang berkelanjutan. Untuk itu dimensi dalam prespektif ini diantaranya adalah

a. Motivasi, adalah gambaran dari kepuasan karyawan dengan kebijakankebijakan dari manajemen untuk melakukan hak dan kewajiban diperusahaan.

b. Kesempatan, adalah peluang yang dimiliki para karyawan dalam mengembangkan diri dengan peraturanperaturan perusahaan diterapkan menjdai kepuasan tersendiri.

c. Inovasi, adalah gerakan peningkatan dalam pelayanan publik untuk 
menunjukan bahwa perusahaan merupakan perusahaan yang kreatif dan mengembangakan berdasarkan ide dari karyawan.

d. Kondisi dalam bekerja, adalah gambaran dari suasana lingkungan kerja sama antara manajemen dengan karyawan, dan karyawan dengan pimpinan melalui kerjasama yang dijalin dalam menyelesaikan suatu pekerjaan.

\section{E. Kelebihan Penggunaan Balance Scorecard}

Pada penelitian ini pengukuran kinerja menggunkan pendekatan balance scorecard dikarenakan dari beberapa sumber dikumpulkan sehingga dapat dijelaskan kelebihanya sebagai berikut:

a. Pengukuran kinerja dengan balance score card dapat diukur melalui internal maupun external dengan mempertimbangkan beberapa variabel faktor eksternal sehingga secara konferhensif dalam pengukuranya. Dari beberapa variabel prespektif eksternal diantaranya adalah prespektif kepuasan pelanggan, maka pada pengukuran ini dapat dikatakan bahwa balance score card tidak hanya mengukur pada finansial saja namun dari beberapa variabel seperti bisnis internal, kepuasan pelanggan dapat dijadikan data pengukuran kinerja.

b. Pengukuran kinerja menggunakan balance scorcard dapat menggunakan visi perusahaan itu sendiri, dengan melakukan kinerja yang baik sesuai dengan visi dapat menunjukan adanya keterjalinan hubingan sebab akibat dalam pencapaian visi perusahaan atau organisasi.

c. Penilaian Kinerja dengan Balance Scorecard ini kelebihanya dapat diukur melalui kualitatif dan kuantitatif, dengan prespektif tersebut sasaran strategis perusahaan dapat menggunakan data-data yang bersifat angka maupun deskriptif.

d. Kelebihan yang terakhir dalam penggunaan Balance Scorecard adalah dapat diwujudkan dari berbagai aspek kinerja dan menentukan dalam jangka panjang, dan jangka pendek, sehingga pengukuran lebih fleksibel.

\section{F. Manfaat Balanced Scorecard}

Melalui Balanced scorecard memungkinkan para manajer perusahaan mengukur:

1. Bagaimana unit bisnis mereka melakukan penciptaan nilai saat ini dengan tetap mempertimbangkan kepentingankepentingan masa yang akan datang.

2. Apa yang telah mereka investasikan dalam pengembangan sumber daya manusia, sistem dan prosedur demi perbaikan kinerja di masa depan.

\section{METODOLOGI PENELITIAN DAN TEKNIK PEGUKURAN}

\section{A. Flow Chart}

Sebagai panduan dalam penelitian maka dibuatlah alur atau flowchart yang menerangkan setiap langkah proses dari awal penelitian hingga hasil, untuk lebih jelasnya dapat dilihat berikut:

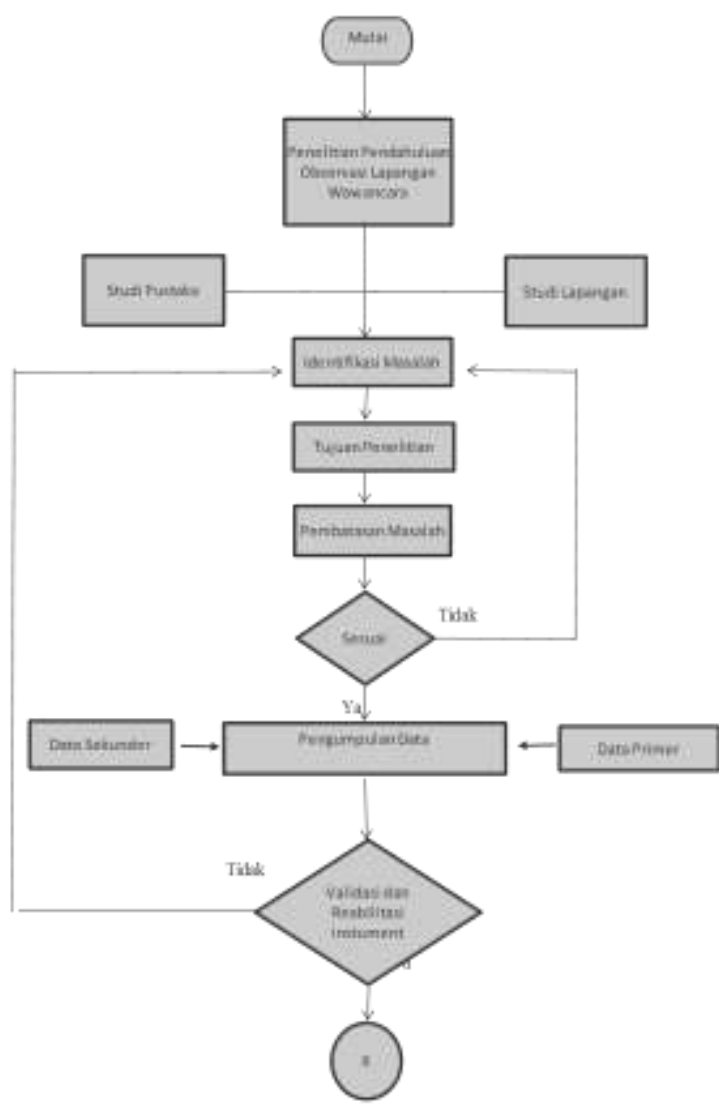

Gambar 3.1 Flow Chart Metode Penelitian Sumber: Pengolahan Sendiri dengan Berbagai Sumber 


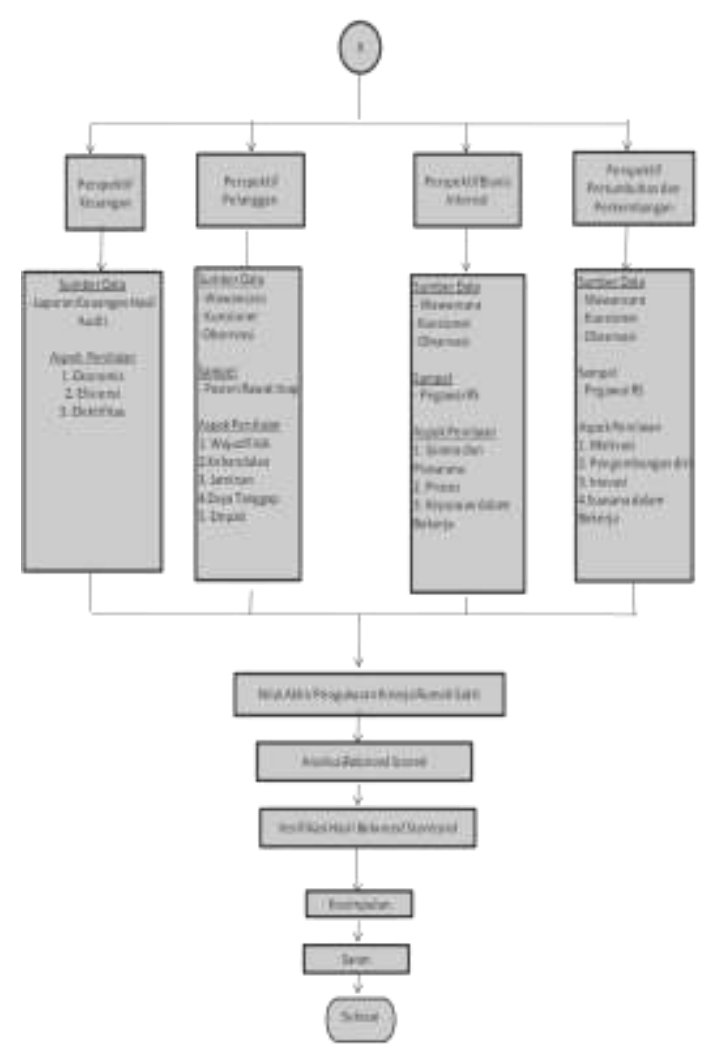

Gambar 3.1 Flow Chart Metode Penelitian Sumber: Pengolahan Sendiri dengan Berbagai Sumber

\section{B. Skala dan Instrumen Pengukuran}

Skala pengukuran dan instrumen pada penelitian ini dengan pendapat dan persepsi masing-masing karyawan, skalanya menggunakan skala likert kelas interval 5 . Sehingga kinerja PT Mulia Artha Anugerah didapat berikut ini:

1. Skala Pengukuran kuesioner Pengukuran pada perspektif kepuasan pelanggan, bisnis internal dan pertumbuhan perkembangan sebagaimana yang ditunjukkan pada tabel 3.2 dibawah ini:

Tabel 3.2 Skala Pengukuran Kuesioner

\begin{tabular}{|c|l|}
\hline Skala & \multicolumn{1}{|c|}{ Kategori } \\
\hline 5 & Sangat Puas/Setuju \\
\hline $4-4,9$ & Puas/Setuju \\
\hline $3-3,9$ & Cukup Puas/Setuju \\
\hline $2-2,9$ & Tidak Puas/Setuju \\
\hline $1-1,9$ & Sangat Tidak Puas/Setuju \\
\hline
\end{tabular}

Sumber: Pengolahan dari berbagai sumber
2. Skala Pengukuran kinerja keuangan sebagaimana yang ditunjukkan pada tabel. 3.1 dibawah ini:

Tabel 3.1 Skala Pengukuran Perspektif Keuangan

\begin{tabular}{|c|c|c|}
\hline Skala & Kategori & $\begin{array}{c}\text { Skala } \\
\text { Likert }\end{array}$ \\
\hline 1. Efisiensi & & \\
\hline$<100 \%$ & Sangat Efisien & 5 \\
\hline $100 \%-110 \%$ & Efisien & 4 \\
\hline $110 \%-120 \%$ & Cukup Efisien & 3 \\
\hline $120 \%-130 \%$ & Tidak Efisien & 2 \\
\hline$>130 \%$ & $\begin{array}{c}\text { Sangat Tidak } \\
\text { Efisien }\end{array}$ & 1 \\
\hline 2. Efektifitas & & \\
\hline$>95 \%$ & Sangat Efektif & 5 \\
\hline $80 \%-95 \%$ & Efektif & 4 \\
\hline $65 \%-80 \%$ & Cukup Efektif & 3 \\
\hline $50 \%-65 \%$ & Tidak Efektif & 2 \\
\hline$<50 \%$ & $\begin{array}{c}\text { Sangat Tidak } \\
\text { Efektif }\end{array}$ & 1 \\
\hline 3. Ekonomis & & 5 \\
\hline$<80 \%$ & Sangat Ekonomis & 5 \\
\hline $80 \%-85 \%$ & Ekonomis & 4 \\
\hline $85 \%-90 \%$ & Cukup Ekonomis & 3 \\
\hline $90 \%-95 \%$ & Tidak Ekonomis & 2 \\
\hline$>95 \%$ & $\begin{array}{c}\text { Sangat Tidak } \\
\text { Ekonomis }\end{array}$ & 1 \\
\hline
\end{tabular}

Sumber: Pengolahan dari berbagai sumber

3. Penentuan populasi dan sampel pada penelitian ini digunakan untuk penentuan populasi serta sampel untuk perspektif pelanggan, perspektif pertumbuhan dan perkembangan serta untuk perspektif bisnis internal.

a. Perspektif Pelanggan

Populasi pada pengukuran perspektif pelanggan adalah populasi dari customer Pertamina diambil dari rata rata pupulasi selama 6 bulan terakhir yaitu sebagai berikut:

$$
\begin{aligned}
& \mathrm{N}=\text { Januari }+ \text { Februari }+ \text { Maret }+ \\
& \text { April }+ \text { Mei }+ \text { Juni } \\
& \mathrm{N}=(268+252+245+270+250+ \\
& 231) \\
& \mathrm{N}=1516
\end{aligned}
$$

b. Penentuan sampel perspektif pelanggan menggunakan Rumus Slovin sebagai berikut:

$$
\mathrm{n}=\frac{\mathrm{N}}{1+\mathrm{N}(\mathrm{e})^{2}}
$$

Keterangan :

$\mathrm{N}=$ Populasi

$\mathrm{e}=$ Tingkat Kesalahan

$\mathrm{n}=$ sampel 
Dari populasi pelanggan sebanyak 1516 dengan tingkat kesalahan $10 \%$, di lihat dari hasil perhitungan dengan Rumus Slovin di peroleh:

$$
\begin{aligned}
& \mathrm{n}=\frac{1516}{1+1516(0.1)^{2}} \\
& \mathrm{n}=93.81
\end{aligned}
$$

dibulatkan menjadi 94 sampel

Kriteria pasien customer yaitu pelanggan yang sudah tetap dalam kontrak selama lebih dari 1 tahun, jika customer tidak bisa menjawab maka di wakili oleh pihak keluarga yang menggantikan selama proses off.

c. Perspektif Bisnis Internal dan Perspektif Pertumbuhan dan Pembelajaran Populasi serta sampel yang digunakan pada perspektif bisnis internal dan perspektif pertumbuhan dan pembelajaran yaitu pegawai PT Mulia Artha Anugerah meliputi karyawan seluruhnya. Penetapan sampel menggunakan rumus Slovin sebagai berikut:

$$
\mathrm{n}=\frac{\mathrm{N}}{1+\mathrm{N}(\mathrm{e})^{2}}
$$

Keterangan:

$\mathrm{N}=$ Populasi

$\mathrm{n}=$ sampel

$\mathrm{e}=$ Tingkat Kesalahan

Dari populasi pegawai sebanyak 180 dengan tingkat kesalahan $10 \%$, di lihat dari hasil perhitungan denga Rumus Slovin di peroleh:

$$
\begin{aligned}
& \mathrm{n}=\frac{180}{1+180(0.1)^{2}} \\
& \mathrm{n}=64.28
\end{aligned}
$$

dibulatkan menjadi 64

Kriteria sampel meliputi pegawai tetap dan honor yang bertugas di PT MAA serta pegawai yang sudah bekerja selama 1 tahun.

d. Validitas dan Reliabilitas

Validitas Instrumen penelitian pada tingkat kepercayaan tertentu $(\alpha)$ ditentukan, jika: $r_{\text {hitung }}>r_{\text {tabel}}$, berarti valid dan jika $r_{\text {hitung }}<r_{\text {tabel }}$, berarti tidak valid. Reliabilitas Instrumen penelitian pada tingkat kepercayaan tertentu $(\alpha)$ ditentukan, jika: $\alpha>r_{\text {tabel}}$, berarti reliabel dan jika $\alpha<r_{\text {tabel, }}$, berarti tidak reliabel.

\section{PEMBAHASAN}

\section{A. Perspektif Keuangan}

Untuk ekonomi, efisiensi dan efektifitas kinerja keuangan dengan menggunakan perhitungan rumus Value For Money Adapun untuk menghitung nilai dari efisiensi, ekonomi, dan efektifitas adalah sebagai berikut:

\section{Ekonomis}

$$
\begin{aligned}
& \text { Ekonomis }=\frac{\text { Realisasi belanja operasional }}{\text { Anggaran belanja operasional }} \times 100 \% \\
& \text { Ekonomis }=\frac{\text { Rp. } 763.555 .645}{\text { Rp. } 900.000 .000} \times 100 \% \\
& \text { Ekonomis }=84.84 \%
\end{aligned}
$$

Dari hasil perhitungan dengan skala likert nilai ekonomis didapat nilai 84,84 $\%$ dan dapat dinilai bahwa PT Mulia Artha Anugerah dikatagorikan ekonomis.

2. Efektifitas

$$
\begin{aligned}
& \text { Efektifitas }=\frac{\text { Realisasi Pendapatan usaha }}{\text { Anggaran pendapatan usaha }} \times 100 \% \\
& \text { Efektifitas }=\frac{\text { Rp. } 880.890 .999}{\text { Rp. } 1.000 .000 .000} \times 100 \% \\
& \text { Efektifitas }=88.08 \%
\end{aligned}
$$

Dari hasil nilai efektivitas didapat dengan nilai $88.08 \%$ sehingga dapat dikatakan bahwa keuangan PT Mulia Artha Anugerah sesuai hasil dikatakan efektif

3. Efisiensi

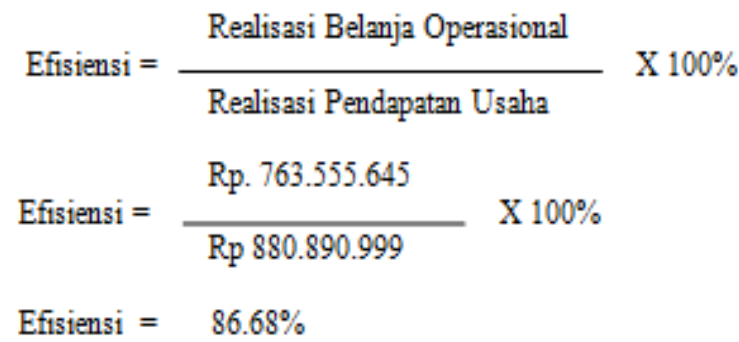


Dari perhitungan diatas ekonomis, efektif dan efisiensi penilaian kinerja PT Mulia Artha Anugerah menggunakan perhitungan Value For Money dapat dilihat pada tabel 4.1 Nilai Kinerja prespektif Keuangan berikut ini:

Tabel. 4.1 Nilai Kinerja Perspektif Keuangan

\begin{tabular}{|c|c|c|c|}
\hline No & $\begin{array}{c}\text { Tolak Ukur } \\
\text { Perspektif Keuangan }\end{array}$ & Nilai & Kategori \\
\hline 1 & Efektifitas & 4 & Baik \\
\hline 2 & Ekonomis & 4 & Baik \\
\hline 3 & Efisiensi & 5 & $\begin{array}{c}\text { Sangat } \\
\text { Baik }\end{array}$ \\
\hline \multicolumn{2}{|c|}{ Rata-Rata } & $\mathbf{4 . 3 3}$ & Baik \\
\hline
\end{tabular}

Sumber: Sugiyono, 2010 Hasil Diolah Kembali

\section{B. Perspektif Kepuasan Pelanggan}

Berdasarkan pembahasan tiap variabel tingkat kepuasan pelanggan maka secara keseluruhan sebesar $\quad 3.62$ sebagaimana yang disajikan pada Tabel. 4.2 berikut ini:

Tabel. 4.2 Nilai Kinerja Perspektif Kepuasan Pelanggan

\begin{tabular}{|c|l|c|c|}
\hline No & $\begin{array}{c}\text { Variabel } \\
\text { Perspektif } \\
\text { Kepuasan } \\
\text { Pelanggan }\end{array}$ & $\begin{array}{c}\text { Nilai Rata- } \\
\text { Rata }\end{array}$ & Kategori \\
\hline $\mathbf{1}$ & Wujud Fisik & 3.19 & Cukup Puas \\
\hline $\mathbf{2}$ & Keandalan & 3.75 & Cukup Puas \\
\hline $\mathbf{3}$ & Daya Tanggap & 3.67 & Cukup Puas \\
\hline $\mathbf{4}$ & Jaminan & 3.77 & Cukup Puas \\
\hline $\mathbf{5}$ & Empati & 3.74 & Cukup Puas \\
\hline \multicolumn{2}{|c|}{ Jumlah } & $\mathbf{3 . 6 2}$ & Cukup Puas \\
\hline
\end{tabular}

Sumber: Data Hasil Penelitian yang Telah di Olah

Jika dilihat secara keseluruhan hasil jawaban responden nilai rata-rata terendah terdapat pada variabel wujud fisik, dengan demikian hal ini perlu menjadi perhatian khusus bagi manajemen PT MAA untuk dapat menyediakan fasilitas perusahaan sebagai salah satu cara untu meningkatkan pelayanan kepada pelanggan.

\section{Perspektif Bisnis Internal}

Penilaian kinerja pada persektif bisnis internal ini dilakukan dengan cara menyebar kuesinoner kepada 64 responden dari 180 orang yang bekerja di PT Mulia Artha Anugerah.

Berdasarkan hasil penjelasan distribusi jawaban responden pada masing masing variabel diatas, sebagian besar responden menyatakan cukup puas atas upaya karyawan PT MAA dalam mendukung tujuan manajemen dengan nilai rata rata tingkat kepuasan pegawai PT MAA yaitu sebesar 3.58, sebagaimana yang ditunjukan pada tabel 4.3 dibawah ini:

Tabel 4.3 Nilai Kinerja Perspektif Bisnis Internal

\begin{tabular}{|c|l|c|c|}
\hline No & $\begin{array}{c}\text { Variabel } \\
\text { Perspektif Bisnis } \\
\text { Internal }\end{array}$ & $\begin{array}{c}\text { Nilai } \\
\text { Rata- } \\
\text { Rata }\end{array}$ & Kategori \\
\hline 1 & $\begin{array}{l}\text { Sarana dan } \\
\text { Prasarana }\end{array}$ & 3.33 & Cukup \\
\hline 2 & Proses & 3.72 & Cukup \\
\hline 3 & Kepuasan Bekerja & 3.71 & Cukup \\
\hline \multicolumn{2}{|c|}{ Jumlah } & $\mathbf{3 . 5 8}$ & Cukup \\
\hline
\end{tabular}

Sumber: Data Penelitian yang Diolah Kembali

Hasil dari Nilai Kinerja prespektif Bisnis Internal diatas variabel sarana dan prasarana paling kecil dengan nilai 3,33\%. Selanjutnya nilai kepusan bekerja $3,71 \%$ dan nilai Proses adalah $3,71 \%$. Sehingga dilihat nilai proses dan kepuasan bekerja mempunyai perbedaan sedikit.

\section{Perspektif Pertumbuhan dan Perkembangan}

Dari hasil penjelasan tiap variabel yang menjadi tolak ukur perspektif pertumbuhan dan perkembangan, maka secara umum penilaian kinerja untuk perspektif ini dapat dilihat pada tabel 4.4 sebagai berikut:

Tabel. 4.4 Nilai Kinerja Perspektif Pertumbuhan dan Perkembangan

\begin{tabular}{|c|l|c|c|}
\hline No & $\begin{array}{l}\text { Variabel Perspektif } \\
\text { Pertumbuhan dan } \\
\text { Perkembangan }\end{array}$ & $\begin{array}{c}\text { Nilai } \\
\text { Rata-Rata }\end{array}$ & Kategori \\
\hline 1 & Motivasi & 3.94 & Cukup \\
\hline 2 & $\begin{array}{l}\text { Kesempatan } \\
\text { mengembangkan diri }\end{array}$ & 3.88 & Cukup \\
\hline 3 & Inovasi & 3.61 & Cukup \\
\hline 4 & Suasana dalam bekeria & 3.85 & Cukup \\
\hline \multicolumn{2}{|c|}{ Jumlah } & $\mathbf{3 . 8 2}$ & Cukup \\
\hline
\end{tabular}

Sumber: Data Penelitian yang diolah kembali 
Dari hasil penilaian kinerja prespektif pertumbuhan dan perkembangan nilai motivasi sebagai nilai yang paling besar dengan nilai 3,94\%. Dan nilai paling kecil adalah nilai inovasi dengan nilai $3,61 \%$. Setelah dirata-rata ke empat variabel prespektif pertumbuhan dan perkembangan didapat nilai sebeasar $3,82 \%$ yang mempunyai arti cukup.

\section{E. Penilaian Kinerja Akhir PT Mulia Artha Anugerah dengan Balanced Scorecard}

Berdasarkan penilaian kinerja pada empat perspektif diatas, maka kinerja PT Mulia Artha Anugerah secara keseluruhan berdasarkan masing masing perspektif dapat dilihat pada tabel 4.5 berikut ini

Tabel 4.5 Penilaian Kinerja Akhir

\begin{tabular}{|c|l|c|}
\hline No & \multicolumn{1}{|c|}{ Perspektif } & $\begin{array}{c}\text { Nilai } \\
\text { Kinerja }\end{array}$ \\
\hline 1 & Perspektif Keuangan & 4.33 \\
\hline 2 & $\begin{array}{l}\text { Perspektif Kepuasan } \\
\text { Pelanggan }\end{array}$ & 3.62 \\
\hline 3 & Perspektif Bisnis Internal & 3.58 \\
\hline 4 & $\begin{array}{l}\text { Perspektif Pertumbuhan dan } \\
\text { Perkembangan }\end{array}$ & 3.82 \\
\hline \multicolumn{2}{|c|}{ Rata-Rata } & 3.83 \\
\hline \multicolumn{2}{|c|}{ Kategori } & Cukup \\
\hline
\end{tabular}

Sumber: Data Penelitian yang Diolah Kembali

Pada tabel 4.5 diatas pada persektif keuangan nilai kinerja PT Mulia Artha Anugerah yaitu 4.33, diartikan baha kondisi keuangan PT Mulia Artha Anugerah baik, tetapi pada perspektif kepuasan pelanggan nilai untuk kinerja PT Mulia Artha Anugerah yaitu sebesar 3.62, yang artinya pelangan PT Mulia Artha Anugerah merasa cukup puas. Dengan skala likert prespektif bisnis internal mempunyai nilai sebesar $3,58 \%$ yang dapat diartikan bahwa kinerja perusahaan cukup baik.

Untuk penilaian kinerja akhir dengan prespektif pertumbuhan dan perkembangan PT Mulia Artha Anugerah dapat digolongkan kinerjanya cukup baik hal ini dibuktikan dengan nilai sebesar $3,82 \%$. Perhitungan ini didapat dengan menggunkan pengukuran skala likert. Jadi untuk nilai kinerja rata-rata dari keempat persektif tersebut didapat nilai akhir kinerja PT Mulia Artha Anugerah yaitu 3.50 dengan kategori kinerja perusahaan cukup baik.
Dalam program kegiatan penilaian kinerja rencana strategis oerganisasi PT Mulia Artha Anugerah merupakan perusahaan yang dapat dikatagotikan sebagai persahaan yang belum maksimal dalam menjalankan programprogramnya hal ini ditunjukan dengan nilai katagori cukup baik.

\section{KESIMPULAN DAN SARAN}

\section{Kesimpulan}

Kesimpulan pada penelitian ini adalah sebagai berikut:

a. Cara yang digunakan PT Mulia Artha Anugerah untuk mengukur kinerjanya selama ini hanya melihat kenaikan atau penurunan profit setiap tahunnya.

b. Setelah mengaplikasikan pengukuran kinerja dengan metode Balanced scorecard hasil penelitian akhir kinerja PT Mulia Artha Anugerah sebesar 3.83 yang dikategorikan cukup baik.

\section{Saran}

Berdasarkan kesimpulan diatas, maka penulis menetapkan saran sebagai berikut:

a. PT Mulia Artha Anugerah perlu lebih memperhatikan fisik perusahaan seperti kebersihan ruang produksi, kenyamanan serta peralatan yang ada di perusahaan. Karena hal tersebut sangat berpengaruh besar terhadap penilaian kepuasan pelanggan dalam menggunakan jasa PT Mulia Artha Anugerah. Dan akan berpengaruh terhadap hasil kinerja.

b. Penulis menyarankan kepada pihak manajemen perusahaan, setelah hasil yang kinerja yang didapat dengan cara mengaplikasikan metode Balanced Scorecad. Maka pihak manajemen PT Mulia Artha Anugerah bisa menerapkan metode Blanced Scorecard tersebut sebagai metode untuk mengukur kinerja perusahaan.

c. Disarankan pula agar dilakukan pelatihan lebih lanjut untuk seluruh karyawan PT Mulia Artha Anugerah, hal ini dimaksudkan untuk dapat meningkatkan kinerja karyawan dimasa yang akan datang. 


\section{V1. DAFTAR PUSTAKA}

Ali, Mutasofiwin. (2002) Balanced Scorecard Tolak Ukur penilaian Pada Badan Usaha." Jurnal Universitas Paramadina. Jakarta. Vol. 1 no 3.

Ancella, Hermawan. (1996). Balanced Scorecard sebagai Sarana Akuntansi

Abdullah, Ongki. (2009). Penerapan Balanced Scorecard Sebagai Tolak Ukur Kinerja Pada RSUD Massenremlu. Skripsi Fakultas Ekonomi dan Bisnis UNHAS Makasar.

Bastuti, S., Zulziar, M., \& Suaedih, E. (2020). Analisis Postur Kerja dengan Metode OWAS (Ovako Working Posture Analysis System) dan QEC (Quick Exposure Checklist) untuk Mengurangi Terjadinya Kelelahan Musculoskeletal Disorders di PT. Truva Pasifik. JITMI Jurnal IImiah Teknik dan Manajemen Industri, 2(2), 116-125.

Hidayat, M. (2018). Analisis Kinerja Perusahaan Dengan Menggunakan Pendekatan Balanced Scorecard Pada Pt. Bosowa Propertindo. 2(1), 92-112. https://doi.org/10.31219/osf.io/gdvq4

Imelda, (2014). Implementasi Balace Scorecard pada organisasi public. Jurnal Akuntansi dan Keuangan Vol. 6. November 2004, pp.106-122

Kaplan, R. S., \& David P. Norton. (1996). The Balanced Scorecard Translating Strategy into Action by Robert S. Kaplan, David P. Norton (z-lib.org).pdf.

Kasmir. (2010). Analisis laporan keuangan. Jakarta: Rajawali Pers

Mahsun, Mohamas. (2009). Pengukuran Kinerja Sektor Publik. Yogyakarta: BPFE

Rangkuti Freddy, (2013). SWOT Balance Scorecard Teknik Menyusun Strategi Korporat yang Efektif plus Cara Mengelola Kinerja dan Rasiko, Jakarta, Gramedia.

Sugiyono. (2002). Metodologi Penelitian. Jakarta: Pustaka Baru

Widodo, I. (2011). Analisis Kinerja Perusahaan dengan Menggunakan
Pendekatan Balanced Scorecard ( Studi Kasus Pada Perusahaan Mebel PT. Jansen Indonesia ). 